УДК: $678.078+664.68$

\title{
RESEARCH OF MICROBIOLOGICAL STABILITY OF PASTERIZED SAUSAGE WITH HEM IRON
}

\author{
M. Polumbryк, V. Pasichnyi, T. Khorunzha, O. Moroz \\ National University of Food Technologies
}

\begin{tabular}{|c|c|}
\hline & ABSTRACT \\
\hline $\begin{array}{l}\text { poultry meat, } \\
\text { cooked sausages, } \\
\text { shelf life, } \\
\text { sodium nitrite, } \\
\text { heme iron }\end{array}$ & $\begin{array}{l}\text { The color of sausage products is of great importance, beca- } \\
\text { use the first thing that draws the consumer's attention is the } \\
\text { appearance of the product. Obtaining the desired color of } \\
\text { sausage products is mainly achieved through the use of sodi- } \\
\text { um nitrite, which is used in the production of cooked sausages. }\end{array}$ \\
\hline $\begin{array}{l}\quad \text { Article history: } \\
\text { Received } 12.11 .2019 \\
\text { Received in revised form } \\
\text { 20.11.2019 } \\
\text { Accepted } 25.11 .2019 \\
\end{array}$ & $\begin{array}{l}\text { The danger of using nitrites is that it is the secondary amines } \\
\text { that are able to react with the nitrites of sausages to form } \\
\text { nitrosamines. } \\
\text { At present, the urgent issue is to find technological solu- } \\
\text { tions that would stabilize the quality of meat and meat pro- }\end{array}$ \\
\hline $\begin{array}{l}\text { Corresponding author: } \\
\text { pasww1@ukr.net }\end{array}$ & $\begin{array}{l}\text { ducts with reduced nitrite content used in the production of } \\
\text { meat products. Current studies on the justification of recipes } \\
\text { and technology of cooked sausage products with a reduction } \\
\text { of the nitrite fraction in sausage formulations are presented. } \\
\text { The question of the possibility of reducing the share of sodium } \\
\text { nitrite due to the increase in the number of pasteurized sau- } \\
\text { sages of color-forming pigment when using the blood of } \\
\text { slaughtered animals is considered. Blood has a color-forming } \\
\text { effect, when administered in the optimal amount, to achieve } \\
\text { the characteristic color of sausage products. In addition, it has } \\
\text { high nutritional and biological value. The influence of the use } \\
\text { of this raw material component on the shelf life of pasteurized } \\
\text { sausage products is shown. } \\
\text { Due to the fact that sodium nitrite acts as an inhibitor of } \\
\text { the growth and development of microorganisms, molds and } \\
\text { their formation of toxins, the effect of added blood of slaugh- } \\
\text { tered animals in combination with sodium nitrite on the micro- } \\
\text { biological stability of cooked sausage products was investi- } \\
\text { gated. According to the biomedical requirements, the growth } \\
\text { dynamics of MAFAMN, BGKP, mold and yeast were investi- } \\
\text { gated as indicators of sausage stability. Microbiological para- } \\
\text { meters were determined immediately after processing (back- } \\
\text { ground values) and pasteurization up to } 45 \text { days of storage. }\end{array}$ \\
\hline
\end{tabular}

DOI: $10.24263 / 2225-2916-2019-26-9$

(C) М. М. Полумбрик, В. М. Пасічний, Т. О. Хорунжа, О. О. Мороз, 2019 


\title{
ДОСЛІДЖЕННЯ МІКРОБІОЛОГІЧНОЇ СТАБІЛЬНОСТІ ПАСТЕРИЗОВАНИХ СОСИСОК 3 ВИКОРИСТАННЯМ ГЕМОВОГО ЗАЛІЗА
}

\author{
М. М. Полумбрик, канд. техн. наук \\ В. М. Пасічний, д-р техн. наук \\ Т. О. Хорунжа, аспірант \\ О. О. Мороз, канд. техн. наук \\ Національний університет харчових технологій
}

Himpuт натрію використовують при виробництві варених ковбас. Небезпека використання нітритів полягає в тому, що саме вторинні аміни здатні реагувати з нітритами ковбас, утворюючи нітрозаміни, тому пошук шляхів мінімізації використання нітритів у виробництві ковбас $\epsilon$ актуальним завданням.

Зважаючи на те, що нітрит натрію виступає інгібітором росту і розвитку мікроорганізмів, плісені й утворення ними токсинів, вивчено вплив доданої крові забійних тварин у поєднанні з нітритом натрію на мікробіологічну стабільність ковбасних виробів вареної групи. Зәідно з медико-біологічними вимогами досліджено динаміку зростання МАФАМн, БГКП, плісняви та дріжджів як показників стабільності ковбас. Мікробіологічні показники визначали одразу після завершення обробки, готові ковбасні вироби - до пастеризації (фонові значення) та після пастеризації до 45 діб зберігання.

Ключові слова: м'ясо птиці, варені ковбаси, термін зберігання, нітрит натрію, гемове залізо.

Постановка проблеми. У сучасних технологіях м'ясопереробної галузі одним iз актуальних напрямів $є$ впровадження у виробництво цільових біологічно активних добавок широкого спектра фізіологічної дії на організм людини [1].

Оскільки одним 3 найбільш поширених захворювань $є$ захворювання серцевосудинної системи, зокрема залізодефіцитна анемія. Пошук технологічних рішень, щодо збагачення гемовим залізом повноцінних харчових продуктів $\epsilon$ актуальним завданням [2]. Для лікування і профілактики залізодефіцитних станів застосовуються як лікарські форми препаратів заліза, так і харчові продукти, збагачені залі3ом [3].

Дедалі більшого поширення в профілактиці і лікуванні залізодефіцитних станів знаходять біологічно активні добавки, що містять залізо в легкозасвоюваній двовалентній формі на основі крові забійних тварин, яка містить гемове залізо в складі гемоглобіну, що легко засвоюється, порівняно з негемовим [3]. Негемове залізо знаходиться у вільній іонній формі - двовалентного $(\mathrm{Fe} 2+)$ чи тривалентного $(\mathrm{Fe} 3+)$ заліза. Значна частина харчового заліза - негемове (міститься переважно в овочах). Ступінь його засвоєння нижчий, ніж гемового, та залежить від низки факторів. Із продуктів харчування засвоюється тільки двовалентне негемове залізо [4].

У зв'язку з вищевикладеним актуальною проблемою є оцінка антибактеріальної активності нітриту натрію та визначення граничної дози його зниження у м'ясопродуктах при використанні крові в рецептурах.

Аналіз останніх досліджень і публікацій. У вітчизняних літературних джерелах показано, що використання крові та добавок із неї в складі м'ясопродуктів зумовлене спорідненістю функціональних властивостей крові і iї технологічних 
властивостей. Відомі розробки добавок із використанням крові і іï фракцій, які рекомендовані для заміни частини яєчних продуктів у рецептурах [7].

Крім того, додавання гемового заліза в ковбасні вироби дасть змогу зменшити залишкову концентрацію нітритів у готовому продукті. У літературних джерелах обговорюється питання застосування природних пігментів крові для забарвлення м'ясних продуктів, в тому числі при їх використанні як природних колорантів [5].

Використання природних пігментів крові для забарвлення м'ясних продуктів $\epsilon$ актуальним, оскільки дасть змогу зменшити застосування нітритів і нітратів під час виробництва м'ясопродуктів. Проте нітрит натрію не тільки фіксує колір м'ясопродуктів, але й впливає на їх мікробіологічну стабільність.

Дослідженнями доведено здатність нітритів гальмувати розвиток різних видів мікроорганізмів (сальмонел, золотистого стафілококу, плісняви) та токсиноутворення, зокрема накопичування афтолотоксину [6].

Дослідження формування споживчих властивостей харчових продуктів, що містять неорганічне і гемове залізо, проводилися як за кордоном, так і в нашій країні. Слід відмітити праці Л. Н. Шатнюк, В. Ю. Міцика, Н. В. Тимошенко, I. В. Леріної, В. В. Свлаш, у яких розроблено асортимент залізовмісних дієтичних добавок і харчових продуктів з їх використанням, а також доведено, що до найбільш ефективних способів корекції дефіциту заліза в організмі людини слід віднести оптимізацію раціонів харчування 3 введенням у них продуктів 3 гемовим залізом.

Традиційні варені ковбасні вироби мають обмежений термін зберігання і вимагають особливих умов зберігання, на відміну від м'ясних пастеризованих сосисок, які завдяки проведеній пастеризації мають набагато довший термін реалізації [8; 9]. У сучасних технологіях пакування набуває поширення новий клас виробів традиційного асортименту, який завдяки використанню фізичних методів впливу на сировину, підвищеним вимогам до організації санітарної безпечності виробництв дає змогу виробляти продукцію подовженого терміну зберігання [9].

При належному підборі рецептурних збагачувачів, цільовому використанню суміжних продуктів, що отримують при виробництві м'яса, в поєднанні з біологічними збагачувачами тваринного походження можливо розробляти нові повноцінні ковбасні вироби цільового призначення. Проте до теперішнього часу питання про широкомасштабне виробництво такого типу харчових продуктів не вирішене і потребує пошуку раціональних технологій використання білоквмісних добавок на основі переробки зокрема і молока [10].

Особливого значення набули розробки з використанням методів, які стабілізують форми гемоглобіну у співвідношенні, що забезпечує певні функціональнотоварознавчі властивості: консистенцію, смак, аромат, вміст власне гему заліза, низьку калорійність, а особливо колір, що свідчить про збереження форм гемоглобіну. Це сприятиме розширенню асортименту продуктів лікувально-профілактичного призначення не лише в м'ясній промисловості, а й, наприклад, у борошняній [11].

Метою дослідження $є$ вивчення впливу крові забійних тварин на мікробіологічну чистоту ковбасних виробів.

Матеріали і методи. У процесі досліджень вивчалась зміна показників ковбасних виробів вареної групи - сосисок пастеризації з різним типом теплового оброблення $з$ і без додаткової пастеризації. Як контроль використовували сосиски Молочні. Для модельних сосисок проведено визначення фізико-хімічних і мікро- 
біологічних показників. У процесі досліджень визначали загальний вміст мікроорганізмів і наявність бактерій групи кишкової палички. Відбір точкових проб для бактеріологічного аналізу проводили згідно з ГОСТ 26669-85. Суть методу визначення загальної кількості мікробів в 1 г продукту полягає в здатності мезофільних аеробних і факультативних анаеробних мікроорганізмів рости на живильному середовищі агар при температурі $37+5^{\circ} \mathrm{C} 3$ утворенням колоній, видимих при п’ятикратному збільшенні. Мікробіологічні дослідження проводили шляхом приготування мазків - відбитків 3 поверхні і глибоких шарів продукту, посівів на живильне середовище 3 подальшим вивченням отриманої культури і підрахунком кількості мікробних тіл в 1 г продукту (ГОСТ 10444.15-94).

Так само проводили бактеріоскопічне дослідження, для якого проби відбирали 3 поверхні із середини продукту.

Для досліджень було виготовлено чотири види сосисок: “Молочні” (контроль), «Курячі», «Традиційні», «Свинні» (згідно з ДСТУ 4436:2005 «Ковбаси варені, сосиски, сардельки, хліби м'ясні. Загальні технічні умови») [9]. У дослідних зразках як кольоростабілізуючий компонент використаний нітрит натрію (0,003\%) у поєднанні $з$ харчовою кров’ю від забою свиней (3\% від маси фаршу), що дало змогу знизити традиційну кількість нітритів на $35 \ldots 45 \%$. Як додатковий смаковий компонент за рекомендаціями [10] додавали олеорезин коріандру. Контрольний зразок виготовляли відповідно до промислової рецептури одночасно з тієї ж сировини за аналогічною технологічною схемою; як кольоростабілізуюча речовина вони містили тільки нітрит натрію в кількостях, передбачених рецептурою $(0,005 \%)$.

У дослідних і контрольних зразках визначали загальну кількість мезофільних аеробних і факультативно-анаеробних мікроорганізмів (МАФАНМ), вміст бактерій групи кишкової палички - БГКП, плісняви та дріжджів. Методи мікробіологічного аналізу відповідали ГОСТ 9958-81 «Вироби ковбасні та продукти з м'яса». Ковбаси кожного виду досліджені в трикратній повторюваності.

Результати досліджень. Згідно $з$ планом дослідження було розроблено рецептури зразків, що відрізнялись видом використовуваної м'ясної сировини та кількістю доданої харчової крові та вологи. Рецептури дослідних зразків представлено у таблиці 1.

\section{Таблиия 1. Рещептури дослідних зразків}

\begin{tabular}{|l|c|c|c|c|c|}
\hline \multicolumn{1}{|c|}{ Сировина } & \multicolumn{2}{|c|}{ «Курячі», \% } & «Традиційні», \% & «Свинні», \% & Контроль, \% \\
\hline Номер зразка, № & 1 & 2 & 3 & 4 & 5 \\
\hline $\begin{array}{l}\text { Червоне м’ясо курчат- } \\
\text { бройлерів }\end{array}$ & 60 & 70 & - & - & - \\
\hline $\begin{array}{l}\text { Біле м’ясо курчат- } \\
\text { бройлерів }\end{array}$ & - & - & 20 & 20 & 20 \\
\hline $\begin{array}{l}\text { Кров свиняча (джерело } \\
\text { гемового заліза) }\end{array}$ & 3 & 3 & 3 & 3 & - \\
\hline $\begin{array}{l}\text { Суха молочна } \\
\text { сироватка }\end{array}$ & 5 & 5 & 5 & 5 & 2 \\
\hline Білковий стабілізатор & 10 & 10 & 10 & 10 & 2 \\
\hline $\begin{array}{l}\text { Концентрат соєвого } \\
\text { борошна }\end{array}$ & 2 & 2 & 2 & 60 & 63 \\
\hline Свинина н/ж & 20 & 10 & 60 & & 2 \\
\hline
\end{tabular}




\begin{tabular}{|l|c|c|c|c|c|}
\hline \multicolumn{1}{|c|}{ Номер зразка, № } & 1 & 2 & 3 & 4 & 5 \\
\hline \multicolumn{4}{|c|}{ Спеції і харчові добавки, у \% до основної сировини } \\
\hline $\begin{array}{l}\text { Сіль, олеорезини } \\
\text { спецій }\end{array}$ & 2,5 & 2,5 & 2,5 & 2,5 & 2,5 \\
\hline Нітрит натрію & 0,003 & 0,003 & 0,003 & 0,003 & 0,005 \\
\hline Лід & 25 & 20 & 20 & 20 & 20 \\
\hline Емулін & 1 & 1 & 1 & 1 & 1 \\
\hline
\end{tabular}

Бактеріологічному дослідженню піддавали сосиски безпосередньо після виготовлення та охолодження, а також після додаткового теплового оброблення пастеризації. Пастеризацію сосисок проводили з використанням скляної тари.

На етапах зберігання за температури $4-6^{\circ} \mathrm{C}$ безпосередньо після виготовлення, в пастеризованих сосисках на 14 і 45 добу визначали зміну МАФАНм, БГКП, кількість пліснявих грибів і дріжджів. Дані про міекробіологічні показники сосисок при зберіганні наведено в табл. 2.

\section{Таблиия 2. Мікробіологічні показники дослідних зразків сосисок}

\begin{tabular}{|c|c|c|c|c|}
\hline № & МАФАМн, КУО/Г & БГКП в 1 г & Пліснява, КУО/г & Дріжджі, КУО/г \\
\hline \multicolumn{5}{|c|}{ До пастеризації } \\
\hline 1 & $1,2 \cdot 102$ & Не виявл. & $2,5 \cdot 101$ & $4,0 \cdot 102$ \\
\hline 2 & $1,1 \cdot 103$ & Не виявл. & $<10$ & $3,0 \cdot 101$ \\
\hline 3 & $5,3 \cdot 102$ & Не виявл. & $<10$ & $<10$ \\
\hline 4 & $7,8 \cdot 102$ & Не виявл. & $<10$ & $9,5 \cdot 101$ \\
\hline 5 & $5,6 \cdot 102$ & Не виявл. & $<10$ & $<10$ \\
\hline \multicolumn{5}{|c|}{ Після 14-денного зберігання (пастеризовані) } \\
\hline 1 & $3,0 \cdot 101$ & Не виявл. & $<10$ & $<10$ \\
\hline 2 & $3,5 \cdot 101$ & Не виявл. & $<10$ & $<10$ \\
\hline 3 & $2,0 \cdot 101$ & Не виявл. & $<10$ & $<10$ \\
\hline 4 & $3,0 \cdot 101$ & Не виявл. & $<10$ & $<10$ \\
\hline 5 & $4,0 \cdot 101$ & Не виявл. & $<10$ & $<10$ \\
\hline \multicolumn{5}{|c|}{ Після 45-денного зберігання (пастеризовані) } \\
\hline 1 & $1,3 \cdot 103$ & Не виявл. & $<10$ & $<10$ \\
\hline 2 & $2,3 \cdot 102$ & Не виявл. & $<10$ & $<10$ \\
\hline 3 & $2,6 \cdot 102$ & Не виявл. & $<10$ & $<10$ \\
\hline 4 & $2,5 \cdot 103$ & Не виявл. & $<10$ & $<10$ \\
\hline 5 & $2,8 \cdot 103$ & Не виявл. & $<10$ & $<10$ \\
\hline
\end{tabular}

Як видно з даних, наведених у табл. 2, загальна кількість мікроорганізмів у 1 г дослідного зразка одразу після виготовлення до пастеризації знаходилася в межах санітарно-бактеріологічних вимог згідно з ДСТУ 4436:2005.

У результаті додаткової термообробки навіть на 14-у добу зберігання кількість мікроорганізмів, плісняви та дріжджів залишалася в межах санітарно-бактеріологічних вимог.

Через 45 діб зберігання в дослідних зразках мікробне число дещо перевищувало допустимі значення для сосисок пастеризованих, зокрема для зразків № 1 та № 4.

У контрольному зразку сосисок без використання гемового заліза кількість МАФАНм була в тому ж порядку значень, що і в дослідних рецептурах з використанням гемового заліза. Дані, наведені в табл. 2, свідчать, що в дослідних і 
контрольних зразках ковбас усіх видів залишкова мікрофлора відповідала санітарним вимогам протягом 14 діб.

Патогенна мікрофлора: сальмонели та спорові сульфітредукуючі анаероби в жодній із проб у досліджувані терміни зберігання виявлені не були (табл. 2).

Можна провести певне порівняння зразків сосисок з використанням м’яса птиці і свинини та харчової крові від забою свиней як джерела гемового заліза та традиційних видів сосисок без використання харчової крові.

Як видно з даних табл. 2, використання харчової крові в рецептурах сосисок пастеризованих практично не має негативного впливу на їхню мікробіологічну стабільність у процесі зберігання при зниженні частки нітриту натрію в складі рецептур. За органолептичними показниками досліджені зразки мали відмінність у межах статистичної похибки.

Висновки. Встановлена можливість зменшення частки нітриту натрію в складі рецептур сосисок пастеризованих при використанні харчової крові від забою свиней без погіршення органолептичних показників виробів.

Доведено відсутність негативного впливу на мікробіологічну стабільність зменшення частки нітриту натрію в рецептурах пастеризованих сосисок при використанні в складі рецептур харчової крові як джерела гемового заліза.

\section{ЛІТЕРАТУРА}

1. Власенко В. В. Використання нізину у виробництві варених ковбас фунціонального спрямування / В. В. Власенко, І. Г. Власенко //Науковий вісник Львівського національного університету ветеринарної медицини та біотехнологій імені С. З. Гжицького. Серія: Харчові технології. - 2016. - №. 18, № 2. - С. 21-26.

2. Кузьминская Е. В. Алиментарные факторы риска возникновения железодефицитных состояний у молодых женщин: дис. канд. мед. наук: 20.09.01. Е. В. Кузьминская - К.: 2001. - 160 c.

3. Noori S. Effects of daily consumption of honey solution on hematological indices and blood levels of mineralsand enzymes in njrmal individuals / S. Noori // Journal of medicinal food. 2003. - Vol. 6, № 2. - P. 135-140.

4. Thomas R. Iron Deficiency in Athletes / R. Thomas // American Journal of Lifestyle Medicine. — 2012. — № 6(4). - P. 319-327.

5. Пасічний В. М. Стабілізація технологічних властивостей ферментованого рису для виробництва м’ясопродуктів / В. М. Пасічний, І. В. Кремешна // Наук. пр. Нац. ун-ту харч. технологій. - 2004. - № 15. - С. 49-50.

6. Святненко Р. С. Вивчення впливу електрофізичних методів обробки на мікробіологічні показники харчових продуктів / Р. С. Святненко, А. І. Маринін, О. В. КочубейЛитвиненко // Техніка, енергетика, транспорт АПК. — Вінниця, 2017. — № 1(96) - С. 125130.

7. Пат. 70714 Україна, МПК (2006) А 23 J 3/00. Білково-жирова емульсія 3 кров’ю / Пасічний В. М., Кремешна I. В., Жук I. 3.; заявник і патентовласник Нац. універ. харч. технологій. — № 20031212348; заявл. 25.12.2003; опубл. 27.08.2007. Бюл. № 13, 2007.

8. Хорунжа Т. Сосиски пастеризовані з підвищеним вмістом гемового заліза / Т. Хорунжа, В. Пасічний, А. Маринін, Р. Святненко, О. Мороз // НВ ЛНУ ветеринарної медицини та біотехнологій. Серія: Харчові технології — 2019 -21(91). — РP. 43-47. doi: 10.32718/nvlvet-f9108.

9. Lee J. J. Sterilization effects of avian influenza virus and newcastle disease virus in chicken muscle and organs dependent on autoclaving time / J. J. Lee // Korean Journal of Veterinary Public Health — 2011. - Режим доступу: http:/lib.rda.go.kr/ newlib/ adlib_en/index.html. 
10. Howe P. Dietary intake of long-chain omega-3 polyunsaturated fatty acids: contribution of meat sources / P. Howe, B. Meyer, S. Record, K. Baghurst // Nutrition. 2006. — 22(1). — PP. 47-53. doi: 10.1016.j.nut.2005.05.0099.

11. Baldassini Welder Angelo Bioanalytical methods for the metalloproteomics study of bovine longissimus thoracis muscle tissue with different grades of meat tenderness in the Nellore breed (Bos indicus) / Welder Angelo Baldassini //Food chemistry. — 2015. — 169. — PP. 65-72.

12. ДСТУ 4436:2005. Ковбаси варені, сосиски, сардельки, хліби м'ясні. Загальні технічні умови. — Увед. 2006-07-01. — К.: УкрНДНЦ, 2006. — 32 с.

\title{
ИССЛЕДОВАНИЕ МИКРОБИОЛОГИЧЕСКОЙ СТАБИЛЬНОСТИ ПАСТЕРИЗИРОВАННЫХ СОСИСОК С ИСПОЛЬЗОВАНИЕМ ГЕМОВОГО ЖЕЛЕЗА
}

\author{
В. Н. Пасичный, М. Н. Полумбрик, Т. О. Хорунжая, Е. А. Мороз \\ Национальный университет пищевых технологий
}

Huтрuт натрия используют при производстве вареных колбас. Опасность использования нитритов заключается в том, что именно вторичные амины способны реагировать с нитритами колбас, образуя нитрозамены, поэтому поиск путей минимизации использования нитритов в производстве колбас остается актуальной задачей. Несмотря на то, что нитрит натрия выступает ингибитором роста и развития микроорганизмов, плесени и образование ими токсинов, при выполнении работы исследовали влияние добавленной крови убойных животных в сочетании с нитритом натрия на микробиологическую стабильность колбасных изделий вареной группы. Согласно медикобиологическим требованиям исследовали динамику роста МАФАМн, БГКП, плесени и дрожжей как показателей стабильности колбас. Микробиологические показатели определяли сразу после завершения обработки (фоновые значения) и после пастеризации до 45 суток хранения.

Ключевые слова: мясо птицы, вареные ковбасы, сроки хранения, нитрит натрия, гемовое железо. 